\title{
Jesaja en die kanonvormingsproses vanaf die agste eeu voor Christus
}

\author{
PM Venter \\ Universiteit van Pretoria
}

\begin{abstract}
Isaiah and the formation of the canon since the eighth century before Christ

The canonisation of Isaiah's words was a complicated process in which different phenomena played a role. Due to politico-historical reasons Jerusalem received symbolic meaning in the Isaiah tradition. Isaiah himself started a prophetic tradition in which Jerusalem was linked to a growing Zion tradition and a monotheising theology of the universal power of God. This tradition became canonical and served as paradigm for understanding the fate of Jerusalem as expression of the sovereign power of God to chastise as well as redeem.
\end{abstract}

\section{CHILDS, TEOLOGIE VAN DIE OU TESTAMENT EN KANONKRITIEK}

\subsection{Childs se tese}

\subsubsection{Ou Testament}

Die navorsing na die teologie van die Ou Testament is deur BS Childs ten nouste met die kanonbegrip verbind. Sedert die sewentigerjare het Childs die standpunt verdedig dat 'the canon of the Christian church is the most appropriate context from which to do Biblical Theology' (Childs 1970: 99). Twee sake is volgens hom van bepalende belang vir die Ou Testamentiese teologie:

* Die kanonieke eindgestalte van die Bybelteks, en

* die geloofsgemeenskap van die vroeë Christelike kerk wat vir die vasstelling van die finale teks verantwoordelik is. 
Childs gee wel toe dat kritiese navorsing na die vorming van die teks en analise van die dieptedimensie van die tradisie daarvan, betekenisvolle eksegetiese inligting kan verskaf (Childs 1987: 248). Dit is egter die finale vorm van die kanonteks wat teologies relevant is. Omdat die kanonvormingsproses, volgens sy beskouing, wesenlik daarom gaan om 'n normatiewe teks daar te stel wat die toekomstige geslagte outoritatief moet aanspreek (Childs 1987: 245), hef die jongste fase van kanonvorming altyd die vorige fases op. Dit is die laaste en finale vorm wat die hoogste gesag dra. Uit daardie vorm blyk die teologiese insigte wat vir die Christelike kerk as norm van geloof gefunksioneer het.

\subsubsection{Profetiese literatuur}

Wanneer Childs die profetiese literatuur hanteer, doen hy dit vanuit hierdie vertrekpunt ('stance') wat die finale kanonvorm as konteks neem. Die finale vorm het tot stand gekom deur 'n 'canonical force' (Childs 1978: 48) wat veral sedert die ballingskap begin werk het. Deur die krag hiervan is 'prophetic oracles which were directed to one generation ... fashioned into Sacred Scripture by a canonical process to be used by another generation' (Childs 1978: 47). Die versamelings profetiese materiaal is losgemaak van hulle oorspronklike historiese raamwerk, selfs van hulle historiese betekenis en is binne 'n nuwe teologiese konteks, die van die finale kanonvorm, geplaas. Die historiese konteks wat deur die histories-kritiese navorsing geskets word, is daarom nie teologies relevant nie. Dit is die finale vorm van die kanon wat teologies die bepalende is. Dit het 'n 'crucial hermeneutical function in establishing the peculiar profile of a passage' (Childs 1978: 48). Dit verskaf die teologiese siening van die godsdiensgemeenskap wat die profetiese literatuur finaal binne die kanon geplaas het.

\subsubsection{Die boek Jesaja}

Ook vir die boek Jesaja (Childs 1979: 311-338) is die hermeneutiese sleutel te vind in die teologiese patroon wat in die finale kanonvorm ('shape') vasgelê is. In daardie vorm word 'n aanduiding gegee van die manier waarop Jesaja se profetiese uitsprake in laaste instansie verstaan moet word. Soos DR Jones, J Becker en PR Ackroyd, is Childs geinteresseerd in die Nachgeschichte van die profetiese komposisie, in die 'actual religious use by those who treasured it' (Childs 1979: 320), die 'historic community's own understanding of the received tradition' (Childs 1979: 321). 
Vir hierdie gemeenskap het profesie gegaan oor die bring van die woord van God. Profesie vind sy vervulling nie in die korrelasie van uitsprake en historiese gebeure nie, "but in terms of the entrance of the reality testified to by the prophetic word' (Childs 1979: 337). Daardie 'realiteit' is 'n bowe-historiese waarheid wat nie aan een historiese tydperk gebonde is nie, maar juis met verloop van tyd al duideliker uitkristalliseer en in die finale kanonvorm geformuleer word. Wat die Jesajaboek in sy kanonvorm aanbied moet nie "historically oriented to its original setting' (Childs 1979: 337) gelees word nie, maar as 'living word of God', as 'n bundel wat deur die redaksionele werk van 'n Deuterojesaja provided a completely new and non-historical framework for the prophetic message which severed the message from its historical moorings and rendered it accessible to all future generations' (Childs 1979: 339). Alhoewel daar in die proses van die kanoniese vormgewing van die Jesajatradisie verskillende wyses was waarop die Jesajamateriaal hanteer en vertolk is, het dit by almal om die gemeenskaplike tema, soos dit in die eindvorm vergestalt is, gegaan, naamlik 'to testify to the ways of God with Israel and the world, both in judgment and in redemption' (Childs 1979: 337). So is uitsprake wat aanvanklik in bepaalde historiese kontekste gefunksioneer het, losgemaak van die algemene historiese situasie en is dit in 'n tydlose kanonvorm geplaas. 'In its new context its message no longer can be understood as a specific commentary on the needs of exiled Israel, but its message relates to the redemptive plan of God for all of history' (Childs 1979: 326).

Hierdie 'theological shaping', met sy tydlose teologiese boodskap, is teweeggebring deur hoofsaaklik die redaksionele werk van Tweedejesaja. Hy het sy werk doelbewus van sy eie historiese konteks losgemaak en dit binne die konteks van die agste eeuse profeet gaan plaas. Sy eie werk, met die oorwegende tema van belofte, is verbind met die werk van Jesaja, met die oorhoofse tema van oordeel. So het 'n nuwe werk vorm aangeneem met die dubbele tema van belofte en oordeel. 'n Dialektiese beweging is sodoende uitgevoer wat aan Eerstejesaja ook die element van belofte toegevoeg het en die element van oordeel aan Tweede- (en Derde-) jesaja. Aan die hand van hierdie 'topical pattern' (Childs 1979: 330) is al die materiaal van Eerstejesaja herrangskik: 'both its older and newer elements have been structured into a clear theological pattern which is integrally connected with Second Isaiah' (Childs 1979: 331). So het in die boek Jesaja 'n kanonteologie tot stand gekom wat losgemaak staan van die oorspronklike historiese omstandighede van die Jesajamateriaal en 'n profetiese teologie daarstel wat in die dialektiek van God se oordeel en God se vergifnis die plan van God uitspel vir die mense van alle eeue (Childs 1979: 327). In lyn met sy beklemtoning van die normatiewe funksie van die kanonieke 'shape' en sy beskouing dat in daardie finale vorm 'the full effect 
of this revelatory history can be perceived' (Childs 1978: 48), vind Childs in die Jesajaboek die teologiese betekenis van beide profesie sowel as van die $\mathrm{Ou}$ Testament: 'the power of the word of God' (Childs 1979: 337). Die gemeenskaplike teologiese tema van die Jesajamateriaal is die getuienis van God se plan, God se woord wat aan die gebeure rigting en betekenis gee, die rigting wat God inslaan met Israel en die wêreld deur oordeel en verlossing.

\subsection{Kritiek op Childs se tese}

\subsubsection{Tyds- en tradisierelevansie}

Childs dink aan die teologie van die OT, as woorde wat vir altyd geld en losgemaak is van een spesifieke historiese situasie. Tog verbind Childs die kanon aan die spesifieke tyd van die godsdiensgemeenskap van die vroeë Christelike kerk. Daar kom inderdaad by hom 'n verabsolutering van die teologiese denkpatroon van een, weliswaar finale, fase in die kanonproses voor. Alhoewel hy 'n kanon sien as 'n tydlose norm, kom hy nie daarvan weg dat die formulering van daardie norm aan 'n bepaalde tyd verbind is nie. Teologies is dit ook nie houdbaar om die teologie van die Ou Testament as tydloos te sien, maar tegelyk te verwag dat dit relevansie vir ons bepaalde tyd moet hê nie. Maar selfs wanneer die teologie van die kanon aan een bepaalde tyd verknoop word is dit ook nog nie in orde nie. In die kanon het ons met die herformulering en finalisering van tradisie in 'n permanente gefikseerde kanonvorm te doen. Die finale vorm kon nie in isolasie gestaan het van die tradisiestroom waarin dit beweeg het nie. Roberts verwys na 'n bepaalde 'inner consistency in the growth of the Isaianic tradition' (Roberts 1987: 63). Die finale vormgewing van die kanon het aangesluit by 'n bestaande teologiese tendens wat reg van die begin af aanwesig was en deur verskeie transformasies heen die samebindende krag van die hele Jesajatradisie gevorm het. In elkeen van hierdie transformasies was beide die teologiese maar ook die sosio-historiese omstandighede van bepalende belang. In Childs se beskrywing van die teologie van Jesaja, van die profetiese en van die Ou Testamentiese literatuur in geheel, gee hy nie aan hierdie aspek van die proses van kanonvorming die nodige aandag nie. Dit blyk uit die kritiek in navorsingskringe op Childs se benadering.

\subsection{2 'n Proses van kanonvorming}

Gese stem volmondig met Childs saam dat die kanonteks die finale maatstaf moet wees vir die teologie van die Ou Testamen. Hy benader die Ou Testament ook 
binne die konteks van die kanon as normatiewe Woord van God. Kanon dui egter by hom op 'n groter samehang as Childs se onthistoriseerde teologie van ' $n$ Christelike geloofsgemeenskap. Inhoudelik sowel as formeel besit die teks eine traditionsgeschichtliche Tiefendimension (Gese 1987: 258). Die teks self, die vorm waarin dit in die eindteks staan, getuig van iets wat in 'n vormingsproses gegroei het. $\mathrm{Na}$ inhoud getuig dit van 'n proses wat in die Lebensvorgängen in Israel gründet (Gese 1987: 260). In daardie proses vind die geskiedenis van God en Israel neerslag in 'n voortganende tradisieproses waarin beide geloofservaring en openbaringskennis hanteer word. Om die Ou Testament as kanon te begryp, beteken om dit binne die kontinuiteit van hierdie kanonvormingsproses te begryp.

Ook by die Praagse skool van Danek word die Verkündigungsgehalt van die teks volgens die Traditionsprozess verstaan (Heller 1982: 219). Die dryfveer agter die tradisieproses was om steeds nuut en aktueel getuienis af te lè. Aan die hand van Zeitgeschichte en inleidingsvrae na die ontstaan en aard van die Ou Testament word gesoek na die 'kerygmatic dynamics of tradition', die 'intention of tradition as the actual impulse of the tradition process itself' (Macek 1987: 91). Die teologie van die Ou Testament kan hieruit geformuleer word sodat die kerk aktualiserend daarby kan aansluit.

Wolff het na hierdie dinamiek van tradisie verwys as die 'Verkündigungswille' (Brueggemann \& Wolff 1982: 12). Die krisis van die ontmoeting tussen tradisie en steeds nuwe gebeure, wat Israel telkens genoop het tot nuwe geloofsantwoorde. word die hermeneutiese vertrekpunt waaruit Wolff die Pentateug verstaan.

Vir Sanders gaan dit om 'dinamiese analogie' (Sanders 1974: 329): die rasionaal agter kanonvorming bied die sleutel vir 'n ooreenstemmende gebruik van tradisie en kanon in die huidige geloofsgemeenskap. Om by die kanonhermeneutiek van die Ou Testament uit te kom, moet die teks teen die agtergrond van die proses van kanonvorming bestudeer word. Naas die gewone histories-kritiese navorsing, vereis dit bestudering van die teks met behulp van navorsing op die gebied van waar en valse profesie, vergelykende midrasj-studie en tradisiekritiek. Die kanonvorm is nie die volle konteks waarin die Ou Testament teologies verstaan moet word nie, maar die vorm moet ook as deel van 'n kanonvormingsproses te midde van historiese, teologiese, sosiale en literêre faktore bestudeer word. Al hierdie verskynsels vorm die konteks waarbinne die funksie van die teks begryp kan word. 


\subsubsection{Jesaja}

Op die vlak van die profetiese literatuur en in besonder die Jesajaboek, blyk dit dat 'n kanonbenadering wat slegs met die eindvorm van die teks werk, nie naastenby voldoende is nie. Sheppard se tradisie-historiese analise van die Jesajaboek aan die hand van die 'anti-Assiriese redaksie' lewer die bewys dat Childs se hantering van die kanonieke 'shape' 'n oorvereenvoudiging is van die materiaal. Aksent op die eindvorm oorbeklemtoon die lyne van harmonie en kontinuiteit in die samestelling van die boek. Dit ignoreer die 'historical discontinuities, conflictual inner-biblical interpretations, and persistent vaguenesses, ambiguities, or contradictory intentions' (Sheppard 1985: 214) wat uit die proses van kanonvorming in die eindvorm tereg gekom het. Die kanonkonteks van die eindvorm is slegs een aspek van 'n teks soos hierdie wat so 'n lang en ingewikkelde groeiproses deurloop het.

Selfs Clements, wat in breë trekke dieselfde benadering as Childs volg, is van mening dat Childs se benadering te veel met ' $n$ latere fase werk waarin ' $n$ voltooide Jesajaboek deel van die kanon geword het. Sy benadering bied geen verklaring vir die huidige vorm van die Jesajaboek self nie. Die navorsing van die redaksiekritiek moet ook in berekening gebring word. Eers wanneer vanuit die redaksionele geskiedenis iets meer oor die huidige vorm van die boek gesê is, 'may we have something to contribute towards the larger issues relating to the canon' (Clements 1985: 97).

Ook by Brueggemann bestaan die oortuiging dat die Jesajaboek meer navorsing vereis as net die van die eindteks binne die kanonkonteks. Daar was sosiale prosesse aan die werk in die vorming van die boek, 'n 'social dynamic' (Brueggeman 1984: 90), wat aan die boek sy bepaalde vorm besorg het. Komplementer tot Childs se benadering moet Gottwald se sosiale benadering gestel word om die eindvorm van die teks te sien as die produk van 'n gemeenskap wat hermeneuties met die tradisie omgegaan het, beide vanuit die historiese realiteit van die gemeenskap en die diakroniese realiteit van die teks: 'The text is more than a text, it is a presentation of a way through to a world of faith' (Brueggemann 1984: 91).

\subsection{Werkwyse}

Wanneer daar in die teologie van die Ou Testament rekening gehou moet word met die kanonkonteks van die Ou Testament, impliseer dit noodwendig die kanonvorm sowel as die kanonproses wat tot daardie vorm gelei het. Die proses en die vorm moet in terme van mekaar gelees word: die proses het die vorm bepaal en die vorm is die resultaat van die bepaalde proses. Die proses is ' $n$ lewende tradisiestroom waarop 'n veelvoud van lewensverskynsels inwerk. Sommige daarvan het 'n meer 
direkte invloed op die proses, ander is weer minder direk. Hierdie verskynsels kan in hoofsaak in drie kategorieë verdeel word: die historiese gebeure in en rondom Israel, die godsdienstig-sosiale struktuur van die gemeenskap in Israel met al sy teologiese tradisies, die kanon wat of as mondelinge tradisie of as geskrif besig is om uit te groei tot die vorm waarin ons dit nou as kanon ken (vgl Venter 1987).

Wanneer hierdie model op die boek Jesaja toegepas word, beteken dit dat die boek teologies gesien moet word as die eindvorm van ' $n$ proses waarin die Assiriese tydvak ' $n$ algemene rol gespeel het, die profetiese optrede van Jesaja en die Jesajatradisie wat dit geskep het 'n meer besondere rol en die literê vorming wat tot die eindelike Jesajaboek gelei het 'n baie spesifieke rol. Dit kan voorgestel word as konsentriese lewensvlakke waar die een saak binne die ander verloop (vgl Venter 1987: 12-24):

Historiese gebeure

Tradisie en profetisme

Kanonvorm

Jesajaboek

Jesajatradisie

Assiriese tyd

Wat vervolgens aangebied word is 'n scenario van die beginfase van hierdie kanonvormingsproses gedurende die agste en sewende eeu vC, wat eventueel uitgeloop het op die huidige boek Jesaja. Vanuit die navorsingstendense en beskikbare gegewens oor onderskeidelik die geskiedenis van hierdie tyd, die verskynsel van profetisme en die profetiese tradisie, en die literatuurvorming van die Jesajaboek word 'n voorstelling gemaak van die vroeëre stadia van die proses wat tot die finale kanonboek gelei het. Veral die teologiese aspekte van die huidige boek word uitgelig en teen hierdie agtergrond verduidelik. Dit is veral die twee temas van 
Jerusalem en die soewereiniteit van God wat telkens na vore kom.

\section{Zeutgescichte}

\subsection{Historiese Relevansie}

Die redaksionele opskrif van die boek Jesaja verbind die optrede van Jesaja van Jerusalem aan die tydperke waarin Ussia, Jotam, Agas en Hiskia oor Juda geregeer het. Die nasionale politiek van Juda gedurende hierdie tyd is die agtergrond waarteen die profeet se optrede gesien moet word. Dit is ook die konteks waarin die betekenis van sy werk verstaan moet word. Die profeet was ' $n$ 'realistic political analyst' (Hayes \& Irvine 1987: 52) wie se prediking ook bepaal was deur die politieke omstandighede van sy tyd. In sy profesie het hy nie alleen by bestaande tradisies aangesluit nie, maar in sy kommentaar op die gebeure van die dag het hy self tradisies geskep wat in die tyd ná hom opgevolg is en op nuwe historiese situasies toegepas is. Sy optrede val saam met 'n wending in die internasionale politiek sowel as die geheel van die kanonvormings-proses. Die ekspansiepolitiek waarmee die Assiriese heerser Tiglat Pileser III in 738 begin het, het die kleiner volke van die oostelike Middelandsesee gebied onder politieke druk geplaas soos hulle nog nooit tevore ervaar het nie. Onder die druk van Assiriese imperialisme ontstaan 'n stryd om oorlewing - polities, nasionaal en godsdienstig. Om in die behoeftes van die godsdiensgemeenskap gedurende hierdie krisisse te voorsien, het 'n nuwe wending in kanonvorming ingetree. Vir die eerste keer het versamelings van profetiese uitsprake begin ontstaan in plaas van die ou biografiese en hagiografiese vertellings, waarin die werke van vroeëre profete soos Elia, Elisa en Natan opgeneem is (Blenkinsopp 1983: 81).

\subsubsection{Assiriē}

Die perspektiewe van Jesaja, die persepsie van sy denke onder sy tydgenote en sy 'support group', soos dit neerslag gevind het in die huidige boek Jesaja, moet histories binne die raamwerk van die laaste helfte van die agste eeu tot en met die eerste helfte van die sesde eeu, verstaan word. Die Assiriese ryk het veral vanaf 738 tot en met die dood van Assur-Banipal in $726 \mathrm{vC}$, direkte invloed uitgeoefen op die bestaan van elke volksgroep aan die oostekant van die Middelandse See tot in Egipte in die suide. Die geskiedenis is telkens bepaal deur die rigting waarin die Assiriese leer beweeg het. Die tye waarin die Assiriese ryk in stryd gewikkel was met vyande uit sy eie omgewing, soos Babilonjë of Anatolië, of wanneer een van sy 
konings te sterwe gekom het, het 'n tyd van herstel vir die volkere oor wie hy geheers het beteken. Dit het telkens uitgeloop op pogings van die kleiner state in Siries-Palestynse gebied om hulle magsposisie te versterk. Grondgebied is by mekaar afgevat of verowerde gebied herwin. Sodra die Assiriese magte weer in 'n gebied aktief raak, loop dit uit op pogings om elke staat se weerbaarheid te verhoog, veral deur in alliansie te gaan met ander state. Die staat wat die deurlopende gunsteling was vir 'n bondgenoot was Egipte, enersyds vanweë sy groter mag, andersyds vanweë sy geografiese verwyderdheid vanaf Assirië en gevolglike groter veiligheid. Die opvallende in hierdie tyd is egter dat die bondgenootskap met Egipte nooit enige noemenswaardige resultate opgelewer het nie. Egipte was self vir 'n geruime tyd onderworpe aan die Etiopiese mag en moes 'n buffer vorm tussen die botsende handelsbelange van die Assiriërs en Etiopiërs in die gebied.

Die koninklike besluitneming in Juda en die nasionaal-religieuse denke van die Jesajagroep is veral bepaal deur die imperiale politiek van die Assiriese ryk. Assirië het sy gebiedsuitbreiding in drie fases laat verloop (Donner by Soggin 1985: 223). Die militêre magte van Assirië het die belange van die ryk uitgebrei deur die eksploitasie van een gebied na die ander. Telkens is 'n nuwe gebied al verder weg van Assirië met brute militêre mag gekonfronteer. Die gebied is 'n vasal van Assirië gemaak, swaar attribuut is opgelê en beperkte selfbeskikking is toegelaat. Indien daar verdere weerstand of rebellie uit so 'n gebied sou kom, is die tweede fase van inkorporering in die ryk toegepas. Die landsbestuur is met militêre ingryping onthef, 'n pro-Assiriese heerser is aangestel en die landsgrense gewysig. Verdere verset het tot die derde fase van imperialisering gelei: die gebied word 'n provinsie gemaak van die Assiriese ryk. Die leierskorps van 'n gebied word in hierdie fase gedeporteer, groepe vanuit ander gebiede van die ryk word in die verowerde gebied hervestig en 'n Assiriese heerser word as regeerder van die gebied aangestel.

Teen die agtergrond van hierdie kruipende imperialisme kan die optrede van Juda, Israel en Sirië verstaan word. Damaskus was een van die sterker magte van die gebied en gevolglik ook een van die sterker teenstanders van Assirië. Die SiroEfraimitiese stryd moet teen die agtergrond gesien word van Damaskus se poging om homself weerbaar te maak teen die aanrukkende Assiriese magte deur gebiedsuitbreiding te onderneem en Israel en Juda in 'n alliansie met hom te probeer indwing. Veral sedert Resin op die troon gekom het in Damaskus in 750 v.C. is Israel, maar ook Juda, ingesleep by die anti-Assiriese aksies. Die samewerking van die konings van Israel met Assirië was dikwels bedoel om 'n teenvoeter te vind vir die aggressiewe beleid van Sirië. Dit was die rede vir Menahem se bereidheid om met Tiglat-Pileser te onderhandel. Wanneer Pileser in 738 weereens die gebied konfronteer, is Menahen se opvolger Peka, 'n persoon wat deur Resin van Damas- 
kus op die troon gestel is. As aangestelde amptenaar oor een van Damaskus se 16 distrikte, is hy gekompromitteer om saam met Damaskus hom teen Assirië te verset. By hierdie geleentheid word Israel saam met Sirië onderwerp en Damaskus word in die eerste fase van imperialisering 'n vasal van Assirië. Agas van Juda is egter nie soos Israel aan Sirië onderhorig nie en gevolglik nie bereid om in 'n alliansie met die twee state teen Assirië te gaan nie. Dit verseker op hierdie stadium die voortgesette soewereiniteit van Juda. Wanneer Resin in 722 in bondgenootskap met verskillende omringende vorste tree en Pileser Damaskus dan in die derde fase van imperialisering 'n provinsie van Assirië maak, verloor Israel slegs grondgebiede rondom Galilea en is hy nie meer onder die mag van Sirië nie. Die rol wat profete soos Amos en Hosea gespeel het in die kritiese beoordeling van die koningshuis van Israel en ook hulle uitgesproke anti-Assiriese houding (vgl Hayes \& Irvine 1987: 40) kon ' $n$ betekenisvolle rol gespeel het in die volgende koning van Israel, Hosea, se opstand teen Assirië by die dood van Tiglat-Pileser en die feit dat Israel onder die Assiriese opvolger Salmeneser ' $n$ volle vasal geword het van Assirië. Ook die verdere weerstand van Israel in 725 deur sy alliansie met Egipte, lei tot die driejarige beleg van Samaria en die uiteindelike verwoesting van die stad deur Sargon II in 722 wanneer Israel die provinsie Samarina word van die Assiriese ryk.

\subsubsection{Jesajatradisie}

By Jesaja kan soortgelyke nasionaal-religieuse simpatieë as by Amos en Hosea veronderstel word. Hierdie geneenthede het egter by die Jesajagroep anders gefunksioneer as in Israel, grootliks vanweë die verskil in politieke opset wat in Juda bestaan het. Die Judese koning Agas het in nasionale belang hom aan Assirië onderwerp en Juda sodoende 'n vasal van Assirië laat word. Deur veral diplomatieke spel het Agas en sy opvolgers daarin geslaag om Juda nooit verder as die eerste fase van imperialisering te laat vorder nie. Juda het onder wisselende politieke aanslae tot aan die einde van die Assiriese ryk nooit meer as 'n vasal van die ryk geword nie. Onder Josia het Juda selfs weer sy soewereiniteit vir 'n tyd lank herwin, alvorens dit onder Nego 'n Egiptiese vasalstaat geword het. Dit was eers in die tyd van Babilonië dat Juda uiteindelik in Augustus 586 onderwerp is en 'n integrale deel van die Babiloniese ryk geword het. Te midde van hierdie geskiedenis waarin Juda voortdurend onder die skadu van die dreigende Assiriese mag gestaan het, maar tog 'n uitsonderingsposisie geniet het vanweë sy geografiese afgesonderdheid, sy politieke en militêre spel met die omringende en verder suidelike state en baie keer doodgewone geluk wanneer dreigende onheil eenvoudig verdwyn, is die Jesajagedagtes gevorm en hêt 'n nalatenskap ontstaan wat kanon- 
tradisie geword het. Hierdie tradisie het gegroei uit standpunte wat die profeet Jesaja ingeneem het ten opsigte van gebeure van daardie tyd en ten opsigte van besluite van die regeerders. Hierdie standpunte was van verskillende aard, soms afkeurend, soms aanmoedigend, na gelang van omstandighede. Die Jesajagroep het egter daarin iets gevind wat aan hulle 'n norm gestel het wat 'n tradisie geword het wat ook in die latere verloop van die geskiedenis van Juda en Jerusalem aktualiteit behou het.

\subsection{Teologiese aspekte van die Jesajatradisie en die historiese agtergrond daarvan}

\subsubsection{Jerusalem}

Jerusalem het in die Jesajatradisie ' $n$ uiters belangrike rol gespeel. Die nasionaalreligieuse sienings van Amos en Hosea, waar die bestaan van die groep en sy nasionale belang godsdienstige betekenis het, is by Jesaja en sy groep, deur historiese omstandighede, verknoop aan 'n stad en sy bestaan in pleks van 'n volk. Jerusalem het deur feitelike omstandighede sinoniem met die godsdiens geword. Andersyds het die politieke bedreiging van die stad en die eventuele verowering daarvan 'n dimensie rondom die Jerusalembegrip gebou by Jesaja en die Jesajagroep, wat die pad oopgemaak het vir die kanonuitbreiding van die latere Jesajaliteratuur. In 'n tyd toe Israel sy soewereiniteit verloor het en die omringende Judese gebiede deur die Assiriese magte verwoes is het Jensalem 'n baie belangrike godsdienstige rol gekry. Jerusalem word die plek waar bestaande teologiese tradisies vanuit die suide sowel as die noorde voortgesit word.

Tradisies oor die kultus, die wet, die kultiese personeel, word van al groter belang namate eers die kultiese sentra van die noorde aansien verloor en daarna sentra in die suide deurloop onder die veroweringstogte van Sanherib. Hulle neem ook in belang af deur die godsdienshervormings en magsentralisering van konings soos Hiskia en later Josia. Tradisies oor die konings, liriese literatuur en wysheidstradisies wat rondom die koningsfiguur gebou is, word al belangriker namate die prestige van die Judese konings toeneem wanneer Juda nie net Israel oorleef nie, maar ook deur die diplomatieke spel van die koning nooit verder ingetrek word as die vasalfase in die Assiriese ryk nie. Gebeure soos die onverklaarbare beëindiging van Sanherib se beleg van Jerusalem, verleen verdere momentum aan die prestige van die koning en lei tot die ontstaan van koningslegendes. Hierdie tradisies word gestimuleer deur noordelike tradisies wat 'n nuwe tuiste vind in Jerusalem. Wanneer Hiskia oorlog voer teen die Fillistynse gebiede en daarin slaag om gebiede te herower wat sy voorganger Agas vroeër moes afstaan, 
lei dit tot ekspansionistiese ideale. Hierdie uitbreiding is egter nie bloot militêr van aard nie, maar loop hand aan hand met Hiskia se godsdiensmaatreëls om ook die noordelike Jahwiste by die feeste en godsdiensaktiwiteite in Jerusalem te betrek. Sulke maatreëls het Jerusalem die tuiste van voormalige noordelike tradisies gemaak. Die optrede van profete uit die noorde, soos Elia en Elisa, die gedagtes van noordelike profete, soos Amos en Hosea, het 'n tuiste gevind in Jerusalem en die weg gebaan vir ontvanklikheid vir die gedagtes van suidelike profete soos Jesaja en Miga. Die godsdienshervormings van die Judese konings, kon grootliks aanleuen op noordelike tradisies, soos veral blyk uit die tyd van Josia, toe Deuteronomistiese denkrigtings baie dienlik was om die godsdiens in Jerusalem te sentraliseer in konkurrensie met die sinkretistiese neigings van die tyd waar plaaslike heiligdomme die probleem van die invloed van die Kanaänitiese en veral die Assiriese godsdiens vererger, eerder as opgelos het.

\subsubsection{God se heilige soewereiniteit}

'n Ander gedagte, wat in die Jesajatradisie baie prominent staan, is die van die soewereiniteit van God. Die anti-Assiriese tendense by die noordelike profete, Amos en Hosea, funksioneer by die Jesajagroep ook met die eintlike betekenis van bevestiging van die mag van die God van Israel. Dit is die verklaring vir die oënskynlike dualisme in profetiese optrede, wat soms deelname aan 'n alliansie teen Assirië afraai en dan weer enige toegewing aan Assirië self ten sterkste afkeur. Die godsdienshervormings van konings soos Hiskia en Josia was wat die konings aanbetref, deel van hulle politieke strategie om die mag van Jerusalem te konsolideer in die stryd teen Assirië. Dit gaan daarom om ook op godsdienstige gebied alle invloed van die Assiriese godsdiens te neutraliseer en die magsuitoefening van die Assiriese ryk aan bande te lê (Blenkinsopp 1983: 84). Dit is wesenlik 'n saak van godsdiens teen godsdiens, die mag van Jahwe teen die mag van die god Assur. Elke Assiriese oorwinning is gesien as 'n oorwinning vir Assur. Elke suksesvolle optrede van Juda en elke onvolvoerde beleg van Jerusalem is 'n bewys van Jahwe se mag. Daarom is die godsdienshervorming in die profetiese tradisie belangrik, hoewel ander sake daarin gelees word as wat die koning miskien bedoel het. Uit dieselfde gronde moet die oënskynlike teenstrydige teenkanting teen die koning se antiAssiriese verset met behulp van alliansies, gesien word. Terwyl die godsuiens hervorming ' $n$ mosie van vertroue in Jahwe se soewereiniteit is, is die pogings om by 'n alliansie teen Assirië aan te sluit 'n mosie van wantroue in Jahwe se mag. Dit was die houding van Jesaja teenoor Agas tydens die beleg van Jerusalem deur Peka en Resin; Jesaja se teenkanting toe Juda deelgeneem het aan die opstand teen Sargon 
saam met Egipte, Hamat, die Filistyne, Edom, Moab in 713-711 (Jes 20: 1-6 \& 18: 118); toe Hiskia die inisiatief geneem het in die rebellie teen Assirië by Sargon se dood (Jes 30: 1-5 \& 31: 1-4) en Jesaja Hiskia se onderwerping aan Sanherib as 'suurberou' beskryf het (22: $1-4$ ). In die lig van hierdie tradisie wat Jesaja geskep het moet die latere waardering vir Josia se optrede verstaan word. Josia herstel nie net 'n tydperk van politieke onafhanklikheid nie, maar word met 'n godsdienstradisie verbind waar die monoteïstiese God wat met 'n verbond aan sy volk verbind is, baie prominent staan. Iets van die verbintenis tussen nasionalisme, godsdiens en die oortuiging van God se almag, wat in die Jesajatradisie gevorm het, kom by Josia tereg. 'He was to achieve the crystallization of faithfulness to the God of Israel, as found in various groups and leaded by the prophets, into a political option' (Soggin 1985: 240).

\subsection{Beperking van die historiese aspek}

Terwyl die kanontradisie wat in die Jesajaboek neerslag gevind het, in noue samehang met die historiese verloop van gebeure staan, blyk dit tog dat bepaalde sienswyses en gedagtes vorm aangeneem het wat hierdie gebeure oorleef het. Dit het 'n soort tradisie geword wat die eienskap gehad het om ook in totaal ander historiese omstandighede 'n bepaalde aktualiteit te hê. Die kanongehalte van hierdie tradisie kan ook nie bloot uit die historiese gebeure waaruit hulle gespruit het verklaar word nie. Ook verdere faktore het tot hierdie kanonieke tradisievorming bygedra, soos die rol van die profeet in die samelewing van daardie tyd.

\section{PROFETE EN TRADISIE}

\subsection{Rolvervulling van die profeet}

Wanneer die huidige kanonstruktuur as die groeiproduk van tradisionele geloofsgemeenskappe gesien word, moet die profetiese literatuur in die kanon ook verstaan word volgens die rol wat die profete binne die godsdiens-gemeenskap gespeel het en die manier waarop profetiese uitsprake verstaan is. Volgens die jukstaposisie van Torah en Profete in die eindversameling van die kanon, lei Blenkinsopp af dat die kanonvormingsproses gekenmerk was deur konflikterende gesagsaansprake om die gesaghebbende tradisie of op profetiese wyse of langs legalistiese weg te vertolk. Wanneer die nasionale krisis van die Assiriese imperialisme in die agste eeu intree, is dit vir Blenkinsopp 'no accident that the writing down of prophetic oracles dates from that time, the first direct attestation being in Isaiah' (Blenkinsopp 1977: 5). 
Teenoor hierdie poging om die tradisie in die aangesig van die krisis gesaghebbend te interpreteer volgens profetiese modus, volg kort daarna die teenbeweging om die nasionale lewe te herorganiseer deur middel van die tradisie in die vorm van die JEepos en deur die promulgering van die Deuteronomistiese wet in die tyd van Josia.

Al is hierdie teorie van Blenkinsopp nie oortuigend nie, is dit tog duidelik dat die profetiese optrede as onderdeel van ' $n$ breër kanonvormingsproses gesien moet word en ook binne die konteks van die samelewing en sy tyd beoordeel sal moet word. Die profetiese tradisie moet verstaan word

... in the context of the interaction of original oracles, later tradents such as disciples or scribes, and the religious community that not only allows its identity to be shaped by the tradition, but by its outlook also indirectly shapes the tradition as well (Meade 1986: 23).

Hoewel dit hier om godsdiensgemeenskappe gaan, is die sosiologiese navorsing van Max Weber en Peter Berger van belang. Berger het aangetoon dat die profete geen geïsoleerde individue was nie, maar deel was van die sosiale instellings en institusionele strukture in Israel (Tucker 1985: 352). Tipiese profetiese verskynsels, soos ekstase, moet as sosiale determinante in die strukture en kulturele area oor die algemeen, gesien word (Blenkinsopp 1983: 35). Daar bestaan goed-gedefinieerde tradisionele patrone waarvolgens die rol van die profeet in die gemeenskap bepaal word. Indien die profeet radikaal van hierdie verwagte vorms sou afwyk, loop hy die risiko om totaal geïgnoreer te word (Wilson 1987: 6).

Binne die verwagtings van die gemeenskap rondom die profetiese rolvervulling, oefen die profeet sy rol uit of om bepaalde sosiale ordes te handhaaf of om die gemeenskap tot sosiale of politieke verandering te beweeg (Wilson 1987: 10). Vór die optrede van Amos was dit in hoofsaak die lede van die koningshuis tot wie die profeet hom gerig het. Met die 'politieke mobilisering van die publiek' waar die Assiriërs die breë samelewing by die onderwerping van vasalverbonde (vgl 2 Kon 18) betrek, word ook die profeet by die politieke besluitneming betrek. Van die vier sosiale groepe in die bevolking - die gewone burger, die invloedryke grondeienaars, die uitvoerende amptenare van die koning en die koningshuis - hoort die profeet tot die tweede invloedryke groep, 'the landowning upper classes ... which constantly plays its part in the mastery of political problems' (Long 1983: 68). Ooreenkomstig die tradisionele rol van die profeet en vanuit die sosiale groepering van die grondbesitters oefen die profeet invloed uit op 'n manier wat ten nouste saamhang met die charisma van sy persoon en die godsdiensverwagting wat die koning en die volk van hom het. 
Die profeet is na eie oortuiging en na verwagting van die godsdiensgemeenskap die persoon wat die wil van God vertolk. Hiervan is verskillende vorms van profetiese optrede (ekstase, simboliek) sprekende getuies. Hy tree by verskillende publieke plekke op. Dit kan by die publieke kultus of aan die koningshof wees. Hy kan ook op verskillende wyses te werk gaan, soos met beeldryke en retoriese taal, of met ritmiese en poëtiese taal, op sangtoon, met dramatiese simboliese gebare, in die 'street theatre itself which teaches us to understand the prophets not only as theologians of a meditative bent, but also as showmen, as experts in public agitation and propaganda' (Long 1983: 81).

\subsection{Die profeet en die wil van God}

Die profete het alle moontlike vorms aangewend om die hoorders te oortuig dat hulle uitsprake die vertolking van God se wil is, hoe onpopuler dit wat hulle sê ookal mag wees. Dit gaan ook nie by die profeet om 'n uitgewerkte politieke program nie, maar om besluite en dade in die bepaalde historiese omstandighede waarin die reg en geregtigheid van God 'n vaste plek het. Uit die roepingsrapport van die profeet blyk dat hy sy rolvervulling gesien het as die van 'n persoon wat in 'a mental state of intense inspiration' (Lindblom by Tucker 1985: 350) verkeer, wat kommunikeer met God 'through a form of perception transcending normal spatiotemporal limitations' (Buss 1980: 6). Hulle moet funksioneer as 'channels through which divine messages reach the ordinary world and through which humans can gain direct access to the divine' (Wilson 1987: 6).

Die rolverwagting wat die gemeenskap van die profeet het is dat hy iemand moet wees wat die regte inligting kan verskaf sodat die besluitnemers die regte besluite sal kan neem. Die uitsprake van die profeet word in die tradisie ook telkens geplaas binne 'n bepaalde wêreld-historiese konteks: die inligting wat die profeet verskaf, het 'n presiese historiese funksie. 'They steer Israel through great historical changes' (Wolff 1987: 16). Hierin lî ook die sleutel om te begryp hoe profetiese uitsprake kanontradisie geword het. Enersyds word aanvaar dat die profeet toegang het tot die wil van God self met al sy verwagte attribute van sinvolheid, samehangendheid, konstantheid, algemeen geldigheid. Andersyds is daar die 'interpretive process of prophetic revelation' (Meade 1986: 21). Die profetiese kommunikasie met sy tydgenote opereer binne die drie kennisvelde van die nasionale tradisie, profetiese tradisie en polities-historiese kennis. Die profeet moet sy Goddelike inligtingsbron ontgin en binne hierdie kennisvelde sy inligting aanbied as wereld relevante inligting wat die historiese besluitnemingsproses kan dien. 


\subsection{Die profeet en kanontradisie}

Deur sy vertolking van die bowe-tydelike wil van God in terme van die tydelike, skep die profeet 'n lewende 'tradition' (Meade 1985: 22). Hy stel 'n proses van Vergegenwärtigung aan die werk. In hierdie proses word relevante inligting vir die bepaalde tyd gegee. Die proses wat aan die gang gesit is oorleef egter die profeet en sy tyd. Die patroon en die styl waarvolgens die profeet sy inligting op omstandighede toegepas het, bly voortleef en word 'n teologiese kanontradisie. Die profetiese uitsprake ontketen 'n Nachgeshichte waarin die uitsprake nie 'n traditum word nie, maar waarin die uitsprake juis vanweë die vertolkende aard daarvan 'n formule verskaf waarin die wyse waarop die profeet die wil van God verstaan het en op sy tyd toegepas het, die patroon word vir 'n proses wat op dieselfde denkpatroon steeds nuwe historiese situasies tegemoettree en daarop inspreek. Dit is wat in die Jesajaboek die belangrike is. Jesaja van Jerusalem het, weliswaar in aansluiting by bestaande profetiese tradisies en godsdiens-sosiologiese patrone van sy tyd, 'n bepaalde patroon van vertolking van die wil van God vir sy omstandighede daargestel. Hierdie patroon het 'n Jesajatradisie geword waarby navolgers van Jesaja aangesluit het en ook hulle tyd vertolk het. Dit het 'n kanontradisie geword waarby nog latere geslagte, na wie onder andere verwys word as 'Deutero- en Tritojesaja', aangesluit het. So het hierdie tradisie voortbestaan totdat dit in sy huidige finale vorm gegiet is. In hierdie proses is nie net telkens by bestaande tradisie bygevoeg nie, maar is die oorgelewerde materiaal in sy geheel binne die lewende traditoproses aangepas en hersien. In die huidige Jesajaboek lê dus 'n kern- of basis Jesajatradisie opgesluit. Elke verdere fase van die Jesajatradisie het by die vorige fase daarvan aangesluit. So is 'n bestaande 'Jesajapatroon' gehandhaaf, maar tog telkens aangevul met die toepassing van daardie patroon op nuwe omstandighede. Dit is daardie Jesajapatroon wat die boek tot ' $n$ eenheid saambind. Indien daardie patroon geïdentifiseer kan word, kan die teologie van die boek gevind word. Die ontleding van die opeenvolgende fases waarin die patroon toegepas is, lê nie net die kanonproses bloot nie, maar lê die kanonhermeneutiek van die boek bloot en dui gevolglik ook die teologiese gebruik daarvan as kanongeskrif aan.

\subsection{Ware en vals profesie}

Verskillende faktore was bepalend vir hierdie tradisie. 'n Deurslaggewende faktor wat bepaal of die vertolkingspatroon wat die profeet daarstel kanontradisie sal word, al dan nie, het te doen met ware en valse profesie. Die profeet wat die regte inligting verskaf is die een wie se woorde effektief is. Sy woorde word as kanonieke maatstaf aanvaar. Dit stel 'n patroon daar wat in latere situasies ook effektief tot die wil van God sal lei (Tucker 1985: 355). Die maatstaf vir ware profesie kan egter nie 
bloot gekoppel word aan die plek waar die profeet opgetree het (kultiese profeet, profeet aan die koningshof) nie, ook nie bloot aan die waarword daarvan nie. Aanvaarding van die profeet se woorde het berus op 'n komplekse proses wat telkens bepaal is deur 'n ander rangskikking van faktore, soos profeteroeping, hantering van godsdienstradisie (Torah, vgl Crenshaw 1984: 702), die werking van 'cognitive dissonance' in die gemeenskap (Blenkinsopp 1983: 72) en die bepaalde historiese omstandighede.

Die rol van die profeet Jesaja in hierdie verband, spreek uit die gebeure van 701 toe Sanherib een van sy hoofamptenare na Jerusalem gestuur het om Hiskia tot oorgawe te dwing. In hierdie krisis stuur Hiskia sy paleisbestuurder Eljakim na die profeet Jesaja. Jesaja lui sy woorde met dieselfde formule in as die afgevaardigdes van Sanherib (2 Kon 19: 6) en tree in die situasie dus op as die afgevaardigde van God. Hy is hier die persoon wat direkte toegang het tot God en wat die regte inligting kan verskaf vir die spesifieke historiese situasie om Jerusalem met behoud deur die krisis te stuur. Sy woorde word as waar ervaar en ter harte geneem. In geheel gesien was Jesaja vir oor die dertig jaar aktief betrokke in die politiek van Jerusalem. Hierdie tydperk was gekenmerk deur voortdurende konflik in standpunte met ander profete en die priesters (Jes 28: 7-13). Hy het behoort tot die antiAssiriese party wat vanaf Agas se beslissing tot oorgawe steeds die amptelike regeerdersbeleid teengestaan het (Blenkinsopp 1983: 114). Sy standpunt teen enige anti-Assiriese alliansie (Jes 18: 1-19: 15) toon dat hy 'n denkpatroon gehandhaaf het, waarin hy as individu optree en hom met God identifiseer. Hy kondig aan dat die Here verkiesing en redding sal laat plek maak vir verwoesting en verwerping. Sy uitsprake verskaf die basis vir hierdie oordeel.

\section{Die profeet en die tradisie}

'n Faktor wat reeds genoem is, wat 'n rol gespeel het in die eventuele oorgaan vanaf profetiese uitsprake tot kanontradisie, is die verbintenis van die profetiese uitsprake aan bestaande tradisies binne ' $n$ tradisiestroom. Meer as ' $n$ überlieferungsgeschichte, gaan dit hier nie net oor die teologiese tradisie waarin elke profeet staan of die tradisie-historiese groei van sy uitsprake tot 'n profeteboek nie, maar om die histories-sosiologies en religieus-relevante hermeneutiek van die profetiese tradisie.

Jesaja sluit aan by bestaande teologiese denkrigtings van sy dag, maar soos by die ander 'ware' profete, reflekteer sy hantering van hierdie denkrigting 'a strongly nionotheistic hermeneutic' (Evans 1986: 93). 'n Lys van die meer algemene tradisies waarby Jesaja aansluiting gevind het, sluit in die wetstradisie, Sion- en Dawidstradisies (Von Rad by Tucker 1985: 333), ou Nabye Oosterse etiese tradisies 
en kontemporêre teologiese sienings (Hayes en Irvine 1987: 53) en die profetiese tradisies van Amos en Hosea (Blenkinsopp 1983: 113v). Wanneer gekyk word na die wyse waarop hierdie tradisies in die Jesajaboek tereggekom het, moet daar genuanseerd onderskei word tussen die profeet Jesaja self met sy hantering van hierdie tradisies binne die raamwerk van sy tyd en omstandighede, en die hantering deur latere lede in die Jesajatradisie van Jesaja se hantering van hierdie tradisies. In die kanon is dit eerder die wyse waarop die latere Jesajatradisie die saak hanteer het wat opgeteken is as die hantering daarvan van Jesaja self. In sy navorsing na die wyse waarop die beleg van Jerusalem onder Hiskia deur Sanherib in 701 weerklank gevind het in die tradisie, toon Clements (1980) aan dat Jesaja nie van 'n bestaande uitgewerkte Sionsteologie gebruik gemaak het nie, maar in die wyse waarop hy hierdie gebeure vertolk het 'n patroon daargestel het wat tot 'n uitgewerkte Sionsteologie in die latere Jesajatradisie gelei het. Die profeet Jesaja het wel 'n Sionstradisie tot sy beskikking gehad waarin Jahwe se besondere sorg vir Jerusalem in samehang met sy ondersteuning van die Dawidsdinastie gesien is. In Psalms 46, 48 en 76 bevat hierdie tradisie ook die gedagte dat die beskerming sal plaasvind deur ander nasies af te weer. Wanneer Sanherib in 701 om onverklaarbare redes sy besetting van Jerusalem laat vaar, word iets van die beskermingsmotief en die konflik met die vyande wat die stad bedreig in die kommentaar van Jesaja op hierdie gebeure gereflekteer. In die latere sogenaamde 'Assiriese redaksie' van Jesaja se uitsprake word die beskermingsmotief en konfliktema toegepas op die kwynende Assiriese mag. Dit lei tot 'n volwaardige Sionsteologie met 'n 'doctrine of inviolability' (Clements 1980: 83) waarin die algemene leerstuk oor die beskerming van Jerusalem in die aangesig van enige onderdrukker gehuldig word. Die 'monoteïstiese hermeneutiek' van die profeet lei egter tot meer as een aanwending van hierdie Sionstradisie en meer as een aspek in die Sionsteologie van die latere Jesajatradisie. Terwyl Hayes en Irvine die variasie in die aanwending van die Sionstradisie afhanklik stel van die 'rhetorical situation' (Hayes en Irvine 1987: 55), gaan dit dieperliggend om die oortuiging van die soewereiniteit van God wat onder alle omstandighede geld. Terwyl die Jesajatradisie telkens die uitsonderingsposisie van Jerusalem ter wille van die Dawidsdinastie stel, ontbreek die vergelyking daarvan met Sodom (Jesaja 8: 5-8) nie. Jerusalem en die Dawidsdinastie is sake waardeur God sy grootheid aandui, maar selfs indien die stad en die Dawidshuis onder historiese omstandighede vergaan sal die grootheid van God nog voortbestaan. Deur sy monoteïstiese hermeneutiek skep Jesaja dus die patroon waarvolgens die Sionstradisie en Dawidstradisie in die latere Jesajatradisie en selfs naballingse Deuterojesajatradisie onder verskillende historiese omstandighede nog toegepas kan word. Die hermeneutiese beginsels wat in ander profetiese tradisies 
op die Mosaïese tradisie toegepas is, is in die Jesajatradisie op die Dawid- en Sionstradisie toegepas. 'Isaiah has prophesied that the same God who established the throne of David in the first place, and who himself is Israels true King, can destroy and later restore it (cf. 11: 1)' (Evans 1986: 94).

Terwyl daar nie in die Jesajatradisie enige wetskodes of verbondstipulasies hanteer word nie (Hayes en Irvine 1987: 53), word die verbondsgedagte wel hanteer (Jesaja 24: 5). Dit is 'n bindende verbond met die God wat die verbreking daarvan nie ongestraf laat deurgaan nie. Die ou fondamente van hierdie verbond tussen die universele God en sy maaksels (Jesaja 33: 8) is so diep gewortel dat dit selfs onder nuwe omstandighede sal voortbestaan (Kapelrud 1984: 183). Daar bestaan egter 'n wanopvatting oor die verbond onder die inwoners van Jerusalem. Die alliansie wat Agas met Assirië gesluit het uit vrees vir die Siries-Efraimitiese alliansie, was 'n verbond met die dood (Jesaja 28: 15). Wanneer die profeet na twee gebeure uit die geskiedenis van Israel verwys, Perasimberg en Gibeonhoogte (Jesaja 28: 21), waar God se mag duidelik geword het, dan word die 'monoteïstiese hermeneutiek' waarmee ouer tradisie vertolk word duidelik: Agas het teen God gedraai, teen God se mag en het dus met die dood 'n verbond gesluit (Evans 1986: 96-97).

Blenkinsopp (1983) verdedig die standpunt dat die profeet Jesaja van Amos en in mindere mate van Hosea, gedagtes oorgeneem het en op Juda toegepas het. Temas soos dié oor ontrouheid (Jes 1: 2-3), lied van die wingerd (Jes 5: 1-7), weeuitsprake oor sosiale nalatigheid wat met dieselfde refrein eindig (Jes 5: 8-23) en selfs wat na 'n verwysing na die aardbewing lyk (Jes 5: 25), 'suggest that Isaiah has taken up where Amos left off and his intent is to apply the message of his older contemporary to the Kingdom of Judah' (Blenkinsopp 1983: 113). Terwyl Blenkinsopp 'n saak daarvoor wil uitmaak dat Jesaja se profetiese optrede nie vêr staan van die Efraimitiese profete tradisie nie, gee hy tog toe dat daar verskille is, soos 'n meer pertinente verwysing na Assirië as by Amos, 'n meer positiewe houding teenoor die instelling van die monargie as by Hosea in die noorde en 'n minder direkte konfrontasie met Jerusalem as sy mede suidelike profeet Miga. Hierdie verskille hang natuurlik saam met die unieke historiese omstandighede van Jerusalem in die Assiriese tydperk. Die feit dat Jerusalem nooit verwoes word in Jesaja se tyd nie, nooit verder assimileer as 'n vasalstaat in die Assiriese ryk nie, op 'n stadium de facto 'n stadstaat word terwyl al die omringende blyplekke deur Sanherib ingeneem is en dat die profeet se arbeidsveld 'n enkele stadsgemeenskap was, sou aksente in sy profetiese optrede teweeg bring wat hom van al die ander profete sou onderskei.

Twee sake staan hier sentraal: Jerusalem en die soewereiniteit van God. Die simboliese waarde van Jerusalem as stad van Dawid en as laaste bastion teen 
die pressie van Assiriese mag, kultuur en godsdiens, sou vormende faktore word in 'n Jesajatradisie waarin die vraag oor die soewereine mag van God te midde van historiese omstandighede wat lyk of dit op die teendeel wys, 'n teologiese sentrum gevorm het. Dit is Blenkinsopp se bevinding dat te midde van alles wat Jesaja met ander tradisies gemeen het, 'what is most characteristic of Isaiah is his overwhelming sense of the reality of God' (Blenkinsopp 1983: 118). Jahwe is die Heilige God van Israel, $\mathrm{Hy}$ is die Gans Andere. In Jesaja se hantering van die tradisie loop hy ' $n$ ander pad as enige van sy voorgangers of sy mede 'teoloë' in Jerusalem. 'In these traditions he sees a God who is free to create and destroy, one who demands faith and obedience, and above all else, one who is holy' (Evans 1986: 99). God werk met sy Goddelike mag in die wêreld volgens 'n plan wat nie noodwendig inval by politieke of nasionale strewes nie (Jesaja 14: 24-27, 28: 23-29, 37: 26). Dit is die profetiese taak van die profeet om hierdie realiteit vormend oor te dra aan sy hoorders: 'the vision which is at the core of the prophet's experience must take over and transform political life, the cost of failure being nothing less than disaster' (Blenkinsopp 1983: 118).

Elke ander tradisie waarvan Jesaja gebruik maak, word langs dieselfde weg diensbaar in die Jesajatradisie aan 'n teologie van die soewereiniteit van God. Die polities-ideologiese term 'dag van Jahwe' word in die Jesajatradisie 'n teenvoeter vir die retrospektiewe tradisies wat terugkyk op die aartsvaders en uittog (Long 1983: 78). God se soewereine mag sal in die toekoms manifesteer wanneer Hy met sy mag ingryp en die gang van die geskiedenis volgens sy plan verander. Etiese ideale uit die Ou Nabye Ooste (bv. beskerming van weduwees en weeskinders) en algemene menslike ervaring (die donkie en os se afhanklikheid van hulle versorgers) (Hayes en Irvine 1987: 53), word in die Jesajatradisie betrek op die verhouding tussen die soewereine God en sy volk. Die priesterlike tradisie word in die Jesajatradisie in twee rigtings gebruik. Jesaja ontvang sy roeping in die tempel (Jesaja 6: 16) en dit is daar waar hy bewus word van God se doel. Aan die ander kant is die tempel geen waarborg vir die behoud van die stad nie. Wanneer die tempel verontreinig word deur 'n verkeerde verhouding met God en gevolglike ongeregtigheid (Jesaja 6: 5-7), word Jerusalem ook besoedel (Jesaja 4:4) asook die hele aarde (Jesaja 24: 4-5). God moet dan die weg van loutering en suiwering volg om uit die ruïnes van Jerusalem met die res wat oorgebly het, 'n nuwe begin te maak. 


\section{LITERATUURVORMING EN DIE JESAJABOEK}

\subsection{Redaksiekritiek en kanonkritiek}

Volgens Childs (1979: 311-338) moet die huidige struktuur van die boek Jesaja teruggevoer word na die werksaamhede van Tweedejesaja. In Jesaja l het Tweedejesaja materiaal uit verskillende tydperke van Jesaja van Jerusalem geneem en herrangskik om 'n teologiese samevatting vir die hele Jesajaanse korpus te vorm. In hoofstukke 2-11 is die materiaal so gerangskik dat die temas 'oordeel' en 'eskatologiese verlossing' mekaar deurgaans afwissel. Ook die roepingsrapport in 6: 1-8: 22 is omraam met hierdie dialektiek. Alhoewel die historiese konteks van die Siro-Efraimitiese krisis hier behou word, transendeer die profetiese woord die profeet se eie historisiteit. Die orakels teen die nasies in 13-23, uitgespreek in verskillende tydperke van die profeet se lewe, is saamgevoeg en geïnterpreteer in die liturgie van die verloste gemeenskap in hoofstukke 24-27. Die oordeelsberig in 28-35 word afgesluit met die tipies Deuterojesajaanse profesie oor Sion se toekomstige uitredding in hoofstukke 34 en 35 . Hoofstukke 36-39 antisipeer die Babiloniese ballingskap en vervul binne die kanonkonteks die metaforiese funksie van kommentaar op die dood en wedergeboorte van 'n nasie.

Tucker (1985) wys op die tendens om die samestelling van 'n boek te verklaar vanuit die rangskikking wat dit in die finale redaksieproses ontvang het by Childs, die poging om die teologie daarvan te verklaar uit patrone in die profetiese kanon soos oordeel en heil by Clements, of dit te verky deur ondersoek te doen na die rol van die redaksionele opskrifte in die eventuele kanonieke fiksering van profeteboeke by homself. Oor hierdie verskuiwing van die klem na die eindvorm merk hy op: 'it would be unfortunate if the preference of source criticism - and early form criticism - for the earliest stages of the tradition were simply transformed to the final, 'canonical' form of the text' (Tucker 1985: 344). Dit is korrek om die finale kanonteks as uitgangspunt te gebruik, maar dit moet hanteer word as die finale fase van 'n teks wat gegroei het in 'n kanonproses. 'n Dissipline wat as 'kanon kritiek' bestempel kan word moet ingespan word om met behulp van alle bestaande dissiplines hierdie kanonproses te beskryf. Bronnekritiek en vormkritiek moet naas redaksiekritiek ingespan word om die kanonproses te rekonstrueer. Die literêre vorms van die oorspronklike profetiese uitsprake moet bestudeer word as funksionele uitdrukkingsvorms waarin die profeet sy denke, sy interpretasie van tradisies, sy vertolking van kontemporêre gebeure, alles, op 'n manier verwoord wat 'n profetiese tradisie aan die gang sit. Tradisiekritiek moet nagaan hoe leser of luisteraars respons vanuit eie tyd en omstandighede hierdie profetiese uitsprake as gesaghebbende uitsprake verstaan het, toegepas het, met eietydse konvensie herformuleer 
het en as groeiende kanontradisie deurgegee het. Redaksiekritiek moet die materiaal behandel as 'n kanontradisie wat vanuit 'n oorspronklike kern deur verskeie transformasies gegroei het en 'n volgroeide kanonvorm bereik het wat nou in die kanonbundel opgeneem is.

\section{Die vorming van die Jesajaboek}

\subsubsection{Karakteristiek van die proses}

Die vormingsproses van die Jesajatradisie was gekenmerk deur 'n konstante sowel as 'n veranderlike, 'n 'rhetorical situation' en 'n 'global theme' (Gitay 1983: 220). Daar was enersyds 'n groeiende tema wat deur verskillende transformasies beweeg het sonder om wesenlik te verander. Andersyds was daar 'n lewende situasie waarin hierdie tema telkens opnuut uitgewerk is. Brueggemann verwys na die 'social dynamic' (Brueggemann 1984: 90) agter die vorming van die teks, die hermeneutiese beweging waarin beide die historiese realiteit van die gemeenskap sowel as die diakroniese realiteit van die teks tot sy reg kom. Hy poneer: 'that each of the Isaiahs articulates a specific practice of social transformation' (Brueggemann 1984: 91). Sheppard gebruik redaksionele navorsing om die kanonkonteks histories te lees. Sy analise van die sogenaamde Assiriese redaksie van Jesajamateriaal uit die tyd van Josia, om en by 612 bring hom uit by 'n kanonvorm waarin 'historical discontinuities, conflictual inner-biblical interpretations, and persistent vaguenesses, ambiguities, or contradictory intentions' (Sheppard 1985: 214) ook neerslag gevind het. In elke redaksionele laag kan baie van die materiaal van 'n vorige redaksionele verwerking en selfs ook materiaal van die oorspronklike profetiese orakels nog agterbly, selfs sonder enige redaksionele wysigings daaraan. Volgens Sheppard is in die Anti-Assiriese redaksie baie min verander aan die roepingsrapport soos dit in die huidige 6: 1-8: 8a opgeteken staan. Die toevoeging van 14: 14-27 en toespelings op sleutelbegrippe en motiewe uit vroeëre tradisies in die Anti-Assiriese redaksie, het weer ansienlike verskuiwing in betekenis meegebring (Sheppard 1985: 214). Die kanonteks van Jesaja bied dus slegs 'a partially delimited surface structure or linguistic arena... in which diverse texts are 
to be read together as though they make in common a claim upon the reader' (Sheppard 1985: 215).

\subsubsection{Nachgeschichte en Midrashuitleg}

Indien daar in die kompleksiteit van die huidige Jesajateks en in die lang redaksiegeskiedenis daarvan, wel na sentrale motiewe gesoek moet word, moet gelet word op die Nachgeschichte van profetiese uitsprake en die rol van midrasjeksegese in die profetiese tradisie. Die fenomeen van midrasjuitleg skakel ten nouste met die kanonvormingsproses: 'the process of attributing unique and permanent authority to earlier tradition, i.e. the process of canon, and the emergence of midrashic procedures belong in their initial phases to the study of the formation and shape of the Hebrew Scriptures' (Miller 1984: 596). Midrasjuitleg het verskillende tegnieke toegepas om gesaghebbende tradisies in die vorm van kontemporêre persepsies en belange te klee en omgekeerd die kontemporêre wèreld in terme van die gesaghebbende tradisie te verstaan. Die 'Babiloniese redaksie' van die Jesajatradisie in die lig van die vernietiging van Jerusalem in 586, het steeds binne die grense van die Jesajatradisie gebly. Die herorganisasie van die Jesajatradisie in afwisselende gedeeltes van verwerping en verlossing is nie net gedoen in die lig van historiese omstandighede nie, maar in aansluiting by die bestaande profetiese tradisie. Die simboliese name Sjearjashub en Maharshalalhashbaz 'were double-edged oracles, that could result in judgment or salvation (Meade 1986: 30). Die pedagogiese aard van Jesaja se profetiese optrede het dit moontlik gemaak om in terme van die wysheidsperspektief straf en redding binne die een samehang van 'n ouer se opvoeding en God se plan met sy volk te lees. In die Nachgeschichte van die profeet se woorde kon met midrasjuitleg straf én redding geakkommodeer word en op verskillende situasies toegepas word. Die 'res' wat sal oorbly kon vir mense wat telkens die Assiriese aanslae vryspring, oordeel wat kom, aankondig; dit kon vir mense wat in die Babiloniese ballingskap beland het, toekomstige hoop aandui (Meade 1986: 30).

\subsubsection{Beginfase}

Wanneer redaksiekrities gesoek word na die 'oorspronklike' Jesjawoorde wat die hele Jesajatradisie begin het, bied die navorsing ' $n$ verskeidenheid uiteenlopende opinies aan. Vermeylen en Barth het albei pogings aangewend om 'n omvattende redaksiegeskiedenis van die Jesajaboek uit te werk. Die teorie van 'n Denkschrift in Jesaja 6: 1-8: 18 wat deur Jesaja self saamgestel is, is deur Werner (1985: 1-30) ingekort tot die Agasepisode in 7: 1-17 en deur L'Heureux (1984: 99-119) uitgebrei 
om ook die Wingerdlied (Jesaja 5: 1-7) as oorspronklike Jesajawoord in te sluit. Clements sluit by laasgenoemde aan en meen dat 'n eerste versameling van Jesajawoorde met die Wingerdlied moes begin het (Clements 1987: 50-61). Hierdie standpunt is egter nie op redaksiekritiek gebaseer nie, maar op sosiohistoriese analise. Met verwysing na die Assiriese magsuitbreiding en die rol wat Jerusalem as enigste sentrum van Jahwisme speel, sien Clements die sentrale boodskap van Jesaja ben Amos as een wat in verband gestaan het met die omstandighede en redes vir die politieke ondergang van Israel en Juda (Clements 1987: 56). Brueggemann oordeel vanuit sy analise van sosiale kritiek dat die Jerusalem Jesaja ideologiese kritiek uitgeoefen het deur die historiese omstandighede van sy tyd te konfronteer met die eise wat God stel (Brueggemann 1984: 93-94). Clements is van oordeel dat die tema van die profetiese boodskap wat op dowe ore val, 'n tema is wat deur Jesaja self in sy roepingsrapport uitgespel is en 'was thereafter taken up by the later prophet of the Babylonian exile and by at least two groups of editors who used it to shape and interpret the material which they helped to compile' (Clements 1987: 58).

\subsubsection{Verdere verloop}

In die verdere oorlewering van Jesajamateriaal vind twee dinge plaas: daar is kontinuïteit en diskontinuïteit in die nalatenskap van die woorde van Jesaja ben Amos. In die huidige Denkschrift (Jesaja 6: 1-9: 6) kom slegs 'n gedeelte voor van 'n oorspronklike meer omvattende beskrywing van die profeet (Jeppesen 1982: 145157). Die oorspronklike verhaal moes 'n beskrywing gehad het oor die profeet se frustrasie met sy roeping. Op 'n stadium in die tradisieproses het hierdie beskrywing verlore geraak, moontlik tydens die 'Assiriese redaksie' (Jeppesen 1982: 156). Sweeney se ondersoek na die wyse waarop materiaal vir Jesaja 13-23 en elders in die Jesaja Apokalips (Jesaja 24-27) gebruik is, dui op 'n tendens om die tekste wat gebruik word te universaliseer. Hierdie tendens was oor die algemeen reeds aanwesig in die teks wat gebruik is. Binne die konteks van Jesaja 24-27 kry die tekste ' $n$ betekenis wat nie altyd korrespondeer met die betekenis wat dit in die vorige konteks gehad het nie. Hulle word eerder in lyn gebring met 'a hermeneutical perspective which is consistent with the universal outlook of Isaiah 24-27, one that looks toward the universal or cosmic significance of God's punishment of the earth and his restoration of Israel in Zion' (Sweeney 1988: 51). Sheppard het aangetoon hoe die dubbele omvorming van Jesaja 6: 1-8: 18 met eerstens uitsprake van oordeel in 5: 25-30 en 9: 7-20 en tweedens sewe orakels in 5: 8-24 en 10: 1-4 'n redaksionele tegniek in die Anti-Assiriese redaksie was wat 'a marked pattern of traces upon which future interpretations of Isaiah 1-39 often depended' (Sheppard 
1985: 213) was. Kontinuïteit is so tussen die uitsprake van Jesaja en die latere Jesajatradisie geskep. Hierdie kontinuïteit word ook deur Clements se analise van Jesaja 10 beklemtoon. In Jesaja 10: 5-15 en 10: 27b-32 kom oorspronklike Jesajamateriaal voor. Die woorde in 10: 16-19 en 10: 33-34 is deur midrasj tegniek geskep en toegepas op die tanende Assiriese mag tydens die regering van Josia. 'n 'secondary midrashic elaboration' (Clements 1980: 45) is toegepas toe 10: 20-23 en 10: 24-27 in die tyd van die nog latere 'Josiaanse redaksie' daarby gevoeg is. 'n $D e$ facto afleiding is gemaak uit die feit dat Sanherib sy besetting van Jerusalem in 701 laat vaar het. Wanneer die Assiriese mag in die tyd van Josia in 'n verswakte posisie verkeer, versterk dit die latere interpretasie van Jesaja se woorde as sou hy die ondergang van Assirië reeds in sy leeftyd voorspel het. Kontinuïteit en eenheid in die wording van die hele Jesajaboek is volgens Clements (1987: 50-61) geskep deur die toenmalige uitsprake van Jesaja teen Jerusalem. Jesaja se woorde het 'n rasionaal gebied vir die lotgevalle van Israel en Juda in die Siro-Efraimitiese krisis van 736, selfs ook toe die Dawidiese monargie en Jerusalemse tempel, wat in Jesaja se tyd as besondere guns van God gesien is, tot 'n val gekom het in die gebeure van 598-586. Die verbinding tussen die eerste 39 hoofstukke en die res van die Jesajaboek 'was especially concerned with the fate of Jerusalem and with the Davidic dynasty' (Clements 1987: 60).

\subsection{Samevatting}

Histories is die geskiedenis van Jerusalem die raamwerk waarin die Jesajatradisie sy kanonvorm ontwikkel het. Die godsdiensgemeenskap was hier gewikkel in die voortdurende krisis van die daadwerklikheid van die verhouding met God. In die Jesajatradisie word hierdie verhouding uitgebeeld as een van oordeel en verlossing. In dit alles gaan dit egter om die plan van God. Hy is die Heilige wat langs sy weg sy wil laat gebeur.

\section{Literatuurverwysings}

BICKERT, R 1987. König Ahas und der Prophet Jesaja. Ein Beitrag zum Problem des syrisch-ephraimitischen Krieges. ZAW 99/3, 361-384.

BLENKINSOPP, J 1977. Prophecy and Canon. A contribution to the study of Jewish origins. London: University of Notre Dame Press.

'BLENKINSOPP, J 1983. A history of prophecy in Israel. Philadelphia: Westminster. 
BRUEGGEMANN, W \& WOLLF, HW 1982. The vitality of Old Testament traditions. Tweede uitgawe. Atlanta: John Knox.

BRUEGGEMANN, W 1984. Unity and dynamic in the Isaiah tradition. JSOT 29, 89-107.

BUSS, MJ 1980. The social psychology of prophecy, in Emerton, JA (ed), Prophecy: Essays presented to Georg Fohrer on his sixty-fifth birthday 6 September 1980. Berlin: De Gruyter.

CHILDS, BS 1970. Biblical Theology in crisis. Philadelphia: Westminster.

CHILDS, BS 1978. The canonical shape of the prophetic literature. Interp. 32, 246-55.

CHILDS, BS 1979. Introduction to the Old Testament as Scripture. London: SCM.

CHILDS, BS 1987. Die theologische Bedeutung der Endform eines Textes. Th $Q$ $167 / 4,242-251$.

CLEMENTS, RE 1980. Isaiah and the deliverance of Jerusalem: A study of the interpretation of prophecy in the Old Testament. Sheffield: JSOT.

CLEMENTS, RE 1985. Beyond tradition-history: Deutero-Isaianic development of First Isaiah's themes. JSOT 31, 95-113.

CLEMENTS, RE 1987. The unity of the Book of Isaiah, in Mays, JL \& Achtemeier, PJ (ed), Interpreting the prophets, 50-61. Philadelphia: Fortress.

CRENSHAW, J 1984. s v Prophecy false. IDB., Supplementary Volume. Nashville: Abingdon.

GESE, $H$ 1987. Der auszulegende Text. ThQ 167/4, 252-265.

EVANS, CA 1986. On Isaiah's use of Israel's sacred tradition. BZ 30/1, 92-99.

GITAY, Y 1983. Reflections on the study of the prophetic discourse: The question of Isaiah 12-20. VT 33/2, 207-221.

HAYES, JH \& IRVINE, SA 1987. Isaiah, the eighth century prophet: His times and his preaching. Nashville: Abingdon.

HELLER, I 1982. Der Traditionsprozess in der Auffassung der Prager Alttestamentler. VT 32/2, 219-224.

JEPPESEN, K 1982. Call and frustration: A new understanding of Isaiah viii 21-22. VT 32/2, 145-157.

KAPELRUD, $H$ 1984. The prophets and the covenant, in Barrick, WB \& Spencer, JR (eds), In the shelter of Elyon: Essays on ancient Palestinian life and literature. In honour of GW Ailström. Sheffield: JSOT.

L'HEUREUX, CE 1984. The redactional history of Isaiah 5: 1-10: 4, in Barrick, WB \& Spencer, JR (eds), In the shelter of Elyon: Essays on ancient Palestinian life and literature. In honour of GW Ahlström. Sheffield: JSOT. 
LONG, B 1983. Monotheism and the prophetic minority: An essay in Biblical history and sociology. Sheffield: Almond Press.

MACEK, P 1987. The Prague School of the Old Testament research and the canonical approach to the Scripture. Communio Viatorum 30/2,89-97.

MEADE, DG 1966. Pseudonimity and canon: An investigation into the relationship of authorship and authority in Jewish and earliest Christian tradition. Tubingen: Mohr.

MILLER, MP 1984. s v Midrash. IDB, Supplementary volume.

ROBERTS, JJM 1987. Isaiah in Old Testament theology, in Mays, JL \& Achtemeier, PJ (eds), Interpreting the prophets. Philadelphia: Fortress.

SANDERS, JA 1974. Reopening old questions about Scripture. Interp. 28, 321-330.

SHEPPARD, GT 1985. The anti-Assyrian redaction and the canonical context of Isaiah 1-39. JBL 104/2, 193-216.

SOGGIN, JA 1985. A history of Israel: From the beginnings to the Bar Kochba revolt, $A D$ 135. London: SCM.

SWEENEY, MA 1988. Textual citations in Isaiah 24-27: Toward an understanding of the redactional function of chapters 24-27 in the Book of Isaiah. $J B L 107 / 1$, 39-52.

TUCKER, GM 1985. Prophecy and the prophetic literature, in Knight, DA \& Tucker, GM (eds), The Hebrew Bible and its modern interpreters. Philadelphia: Fortress.

VENTER, PM 1987. Die kanongeskiedenis van die Ou Testament. Kital: Pretoria.

WERNER, W 1985. Vom Prophetenwort zur Prophetentheologie. Ein redaktionkritischer Versuch zu Jes 6,1-8,18. BZ NF 1, 1-30.

WILSON, RR 1987. Early Israelite prophecy, in Mays, PJ \& Achtemeier, PJ (eds), Interpreting the prophets. Philadelphia: Fortress.

WOLLF, HW 1987. Prophecy from the eighth through the fifth century, in Mays, JL \& Achtemeier, PJ (eds), Interpreting the prophets, 14-26. Philadelphia: Fortress. 